\title{
Bacterivory by co-occurring red-tide algae, heterotrophic nanoflagellates, and ciliates
}

\author{
Kyeong Ah Seong ${ }^{1}$, Hae Jin Jeong ${ }^{1, *}$, Shin $\mathrm{Kim}^{2}$, Gwang Hoon Kim ${ }^{3}$, \\ Jung Hoon Kang ${ }^{4}$ \\ ${ }^{1}$ School of Earth and Environmental Sciences, College of Natural Sciences, Seoul National University, Seoul 151-747, \\ Republic of Korea \\ ${ }^{2}$ MarineBio Co., Kunsan National University, Kunsan 573-701, Republic of Korea \\ ${ }^{3}$ Department of Biology, College of Natural Sciences, Kongju National University, Kongju 314-701, Republic of Korea \\ ${ }^{4}$ Southern Coastal Environment Research Division, South Sea Institute, KORDI, Changmokmyun, Koje 656-830, \\ Republic of Korea
}

\begin{abstract}
We investigated feeding of natural populations of red-tide algae, heterotrophic nanoflagellates (HNFs), and ciliates $(<30 \mu \mathrm{m}$ in cell length) on natural populations of marine bacteria (mostly heterotrophic bacteria) in diverse Korean waters (Masan Bay, Jinhae Bay, Shiwha Bay, Keum River estuary, and the open coastal waters off Yeosu) during red tides in 2004 to 2005. To explore the functional responses of the dominant red-tide algae to bacteria, we also measured the ingestion rates of the dinoflagellates Cochlodinium polykrikoides, Heterocapsa rotundata, H. triquetra, and Prorocentrum minimum as well as the raphidophytes Chattonella ovata and Heterosigma akashiwo as a function of bacterial concentration in the laboratory. During red tides, ingestion rates of the red-tide algae $C$. polykrikoides, $H$. rotundata, $H$. triquetra, $H$. akashiwo, $P$. minimum, and $P$. triestinum on natural populations of bacteria in Korean waters (1.2 to 20.6 cells alga $\left.{ }^{-1} \mathrm{~h}^{-1}\right)$ were comparable to those of co-occurring HNFs ( 0.7 to 39.4 cells $\mathrm{HNF}^{-1} \mathrm{~h}^{-1}$ ), but much lower than those of co-occurring ciliates (15 to 713 cells ciliate ${ }^{-1} \mathrm{~h}^{-1}$ ). However, the combined grazing coefficients attributable to the dominant algal predators on natural populations of bacteria during red tides (0.04 to $\left.1.71 \mathrm{~d}^{-1}\right)$ were usually higher than those attributable to co-occurring HNFs $\left(0.01\right.$ to $\left.0.20 \mathrm{~d}^{-1}\right)$ or ciliates $\left(0.00\right.$ to $\left.0.72 \mathrm{~d}^{-1}\right)$. With increasing mean prey concentration, the ingestion rates of $C$. polykrikoides, $H$. rotundata, $H$. triquetra, P. minimum, C. ovata, and $H$. akashiwo on bacteria rapidly increased at prey concentrations of ca. 5 to $10 \times 10^{6}$ cells $\mathrm{ml}^{-1}$, and slowly increased or became saturated at higher prey concentrations. The maximum ingestion and clearance rates of $C$. polykrikoides, $H$. rotundata, $H$. triquetra, $P$. minimum, C. ovata, and $H$. akashiwo on bacteria (6 to 25 cells alga ${ }^{-1} \mathrm{~h}^{-1}$ and 1.0 to $4.5 \mathrm{nl} \mathrm{alga}^{-1} \mathrm{~h}^{-1}$ ) were comparable to those so far reported in the literature of HNFs on bacteria. The results of the present study suggest that, potentially, red-tide algae can have a considerable grazing impact on populations of bacteria during red tides and are sometimes the most effective protistan predators of marine bacteria.
\end{abstract}

KEY WORDS: Bacteria $\cdot$ Graze $\cdot$ Harmful algal bloom $\cdot$ Ingestion $\cdot$ Marine $\cdot$ Protist $\cdot$ Red tide

\section{INTRODUCTION}

Marine bacteria are one of the major components in marine ecosystems (e.g. Azam et al. 1983), and they sometimes dominate marine plankton biomasses or particulate organic carbon (Cole et al. 1988, Cho \&
Azam 1990). Heterotrophic nanoflagellates (HNFs) and ciliates are also major components of marine food webs (McManus \& Fuhrman 1988, Bloem \& BarGilissen 1989, Patterson \& Larsen 1991). It has been reported that HNFs and/or small ciliates are major predators of marine bacteria and occasionally control 
the populations of marine bacteria (Fenchel 1982, Azam et al. 1983, Sieburth 1984). However, it has been suggested that microorganisms other than HNFs and/or ciliates may sometimes affect the populations of marine bacteria (e.g. Vaque et al. 2002).

Recently, many red-tide algae have been revealed to be mixotrophic (Bockstahler \& Coats 1993, Chang \& Carpenter 1994, Jacobson \& Anderson 1996, Granéli et al. 1997, Stoecker et al. 1997, Legrand et al. 1998, Stoecker 1999, Skovgaard et al. 2000, Smalley et al. 2003, Jeong et al. 2004, 2005a,b,c). They are capable of obtaining nutrition by photosynthesis and/or predation. If red-tide algae ingest bacteria in a significantly large number, they may compete with HNFs and ciliates for bacterial prey, and the grazing impact by the algae on bacteria may make a considerable contribution to the total grazing impact of protistan predators on bacteria. However, there have been few studies on the feeding of red-tide algae on marine bacteria (Nygaard \& Tobiesen 1993, Jeong et al. 2005a), although there have been many studies on the interactions between red-tide algae and algicidal bacteria (Kim et al. 1998, Doucette et al. 1999, Imai et al. 2001, Skerratt et al. 2002, Mayali \& Azam 2003). Nygaard \& Tobiesen (1993) reported that some prymnesiophyte species, the raphidophyte Heterosigma akashiwo and the dinoflagellates Karlodinium micrum (previously Gyrodinium galatheanum) and Alexandrium tamarense were able to ingest bacteria, but $H$. akashiwo and $K$. micrum did not ingest bacteria when the phosphate concentrations were high (batch cultures, 0.33 to $1.56 \mu \mathrm{M})$. Jeong et al. (2005a) reported that several red-tide dinoflagellates were able to ingest the cyanobacterium Synechococcus sp. However, the feeding and grazing impacts of red-tide algae on bacteria in marine ecosystems remain poorly understood. In the interactions between red-tide algae and marine bacteria, the following questions may arise. (1) Are red-tide algae able to ingest marine bacteria in waters where phosphate and/or nitrate plus nitrite concentrations are high? Many algal species have formed red tides in coastal, bay, and estuarine waters where nutrient concentrations are relatively high (usually $>10 \mu \mathrm{M}$ nitrate plus nitrite and $>1 \mu \mathrm{M}$ phosphate) (e.g. Jeong et al. 2005b). Therefore, it is worthwhile to investigate the feeding of diverse red-tide algal species on marine bacteria in eutrophic waters. (2) Do red-tide algae have considerable grazing impact on the natural populations of marine bacteria? In addition, are the ingestion rates and grazing impact of red-tide algae on the natural populations of co-occurring bacteria comparable to those of HNFs and/or ciliates, considered to be the major predators of bacteria?

There have been no reports on comparisons of the grazing impact by co-occurring red-tide algae, HNFs, and ciliates on the natural populations of marine bacteria. (3) What are the functional responses of redtide algae to bacteria? Further, are the maximum ingestion and clearance rates of red-tide algae on bacteria comparable to those of HNFs and ciliates?

In the present study, we (1) investigated the ingestion rate and grazing impact by the natural populations of cooccurring red-tide algae, HNFs, and ciliates on the natural populations of marine bacteria in several eutrophic Korean waters (Masan Bay, Jinhae Bay, Shiwha Bay, Keum River Estuary, and the open coastal waters off Yeosu) during red tides in 2004 to 2005; (2) examined the functional responses of the red-tide dinoflagellates Cochlodinium polykrikoides, Heterocapsa rotundata, $H$. triquetra, and Prorocentrum minimum and the red-tide raphidophytes Chattonella ovata and Heterosigma akashiwo, which were the dominant species during the red tides when fed on bacteria in the laboratory; and (3) compared the maximum ingestion and clearance rates of red-tide algae on marine bacteria with those of HNFs and ciliates. The results of the present study provide a basis for understanding the interactions between red-tide algae and co-occurring marine bacteria and possible competition among redtide algae, HNFs, and ciliates for bacterial prey.

\section{MATERIALS AND METHODS}

Feeding of protistan predators on bacteria in Korean waters. Water samples were taken from the surface in Masan Bay, Jinhae Bay, Shiwha Bay, Keum River Estuary, and the open coastal waters off Yeosu, Korea, by using water samplers during red tides from December 2004 to August 2005 (Fig. 1). Water temperatures and salinities in the surface waters were measured using a YSI 30 (YSI), and $\mathrm{pH}$ and dissolved oxygen (DO) were measured using pH-11 (Schott Handy-Lab) and Oxi 197i (WTW), respectively (Table 1). Water samples for analyzing nutrient concentrations were gently filtered through GF/F filters and stored frozen at $-20^{\circ} \mathrm{C}$ until nitrate plus nitrite and phosphate concentrations were measured using a nutrient autoanalyzing system (Bran and Luebbe TRAACS 2000). The water samples were transported into the laboratories within 10 to $60 \mathrm{~min}$.

In order to determine the bacterial and HNF abundances, aliquots of the water samples were poured into $100 \mathrm{ml}$ polyethylene bottles and preserved with glutaraldehyde (final conc. $=1 \% \mathrm{v} / \mathrm{v}$ ). Three to twelve $1 \mathrm{ml}$ fixed aliquots were stained with 4'6'-diamidino-2phenylindole (DAPI, final conc. $=1 \mu \mathrm{M}$ ) and then filtered onto 0.2- $\mu$ m-pore-sized polycarbonate (PC) black membrane filters. Bacteria were enumerated under an epifluorescent microscope with UV light excita- 


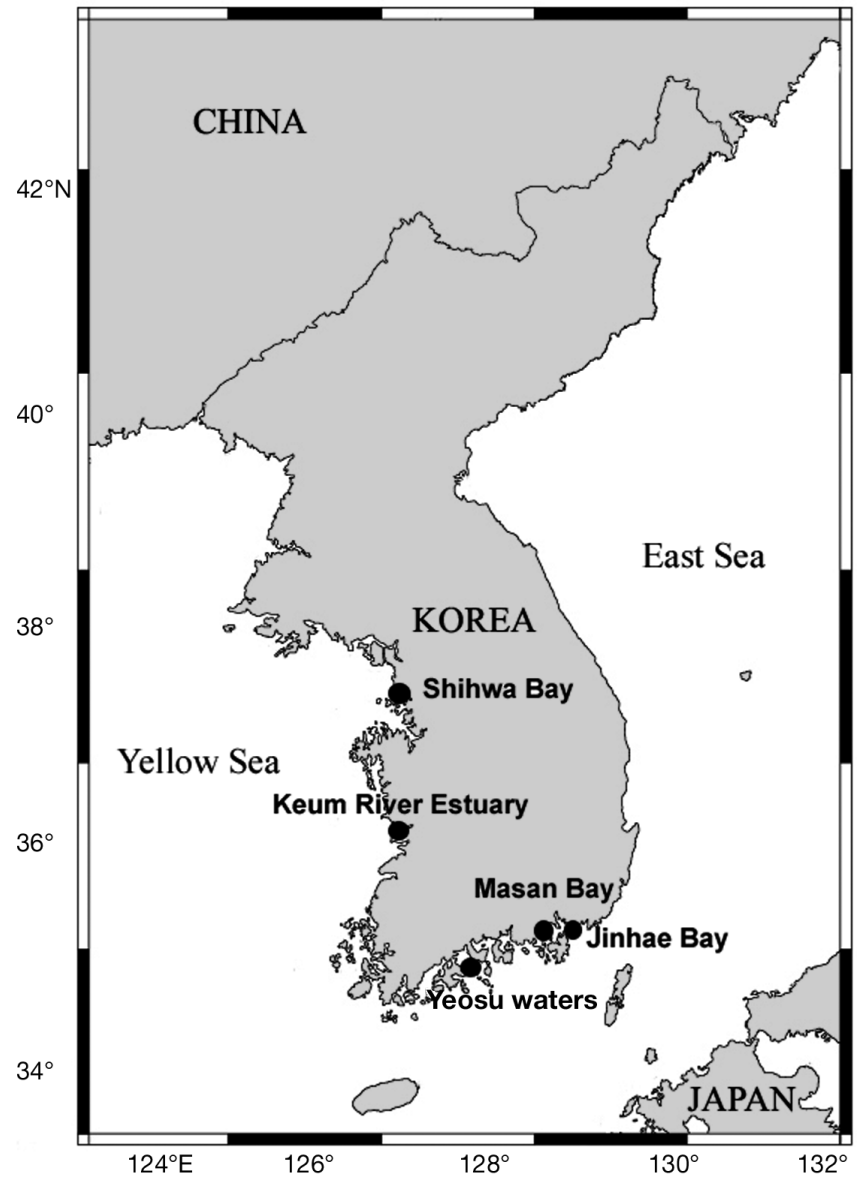

Fig. 1. Map of the study areas (Masan Bay, Jinhae Bay, Shiwha Bay, Keum River Estuary, and the open coastal waters off Yeosu, Korea)

tion (Porter \& Feig 1980). Additionally, three 1 to $5 \mathrm{ml}$ fixed aliquots were stained with DAPI and then filtered onto polycarbonate (PC) black membrane filters of $0.2 \mu \mathrm{m}$ pore sized. HNFs were also enumerated under an epifluorescent microscope with UV light excitation. HNFs could be distinguished from autotrophic nanoflagellates that exhibit orange-colored autofluorescence with blue light excitation. Aliquots of the water samples for counting red-tide algae and ciliates were poured into $500 \mathrm{ml}$ polyethylene bottles and preserved with acidic Lugol's solution. After thorough mixing, >500 algal cells in three $1 \mathrm{ml}$ Sedgwick-Rafter counting chambers (SRCs) and $>20$ ciliate cells in 3 to 11 SRCs were counted under an inverted microscope with standard transmitted illumination.

The samples for the feeding experiments were screened gently through a $30 \mu \mathrm{m}$ Nitex mesh and placed in $270 \mathrm{ml}$ PC bottles. Then, 3 to $4 \mathrm{~d}$ prior to feeding experiments, bacterial cells collected from the same site were fluorescently labeled by the method of
Sherr et al. (1987). These experiments revealed that the fluorescently labeled bacteria (FLB) were mostly seen as rods (a cylinder) and rarely spherical. We measured the longest (length) and the shortest axes (width) of 23 to 27 FLB cells for each field experiment under an epifluorescent microscope, as described in Lee \& Fuhrman (1987), and then calculated the volume according to the following equation: volume $=[\pi(3 L-$ $\left.W) / 3 \times(W / 2)^{2}\right]$ for a rod (cylinder) and $4 / 3 \times\left[\pi R^{3}\right]$ for a sphere, where $L$ is length, $W$ is width, and $R$ is radius, as in Lee (1993). The size of fluorescent beads $(0.47 \mu \mathrm{m}$, size data supplied by the manufacturer, Polyscience) was also measured to calibrate our results. The volumes of FLB and ratios of the actual initial abundance of FLB to the abundances of natural population of bacteria are shown in Table 2. FLB were added to duplicate (Keum River Estuary and Jinhae Bay) or triplicate (Shiwha Bay, Masan Bay, and Yeosu waters). One control bottle (without FLB) was set up for each experiment. The bottles were placed on shelves and incubated at a temperature equivalent to that of the water temperature at the sampling site under continuous illumination of $30 \mu \mathrm{E} \mathrm{m}^{-2} \mathrm{~s}^{-1}$ of cool white fluorescent light.

After 1, 5, 10, 20, and $30 \mathrm{~min}$ incubation, $10 \mathrm{ml}$ aliquots were removed from each bottle, transferred into $20 \mathrm{ml}$ vials, and then fixed with borate-buffered formalin (final conc. $=3 \%$ ). The fixed samples were stained using DAPI (final conc. $=1 \mu \mathrm{M}$ ) and then filtered onto PC black membrane filters of $0.2 \mu \mathrm{m}$ pore size. Green inclusions (FLB) inside the protoplasm of 50 to 70 cells of red-tide algae and 10 to 30 cells each of HNFs and ciliates on the PC black membrane filters were enumerated under an epifluorescent microscope with blue light excitation. The ingestion rate (cells predator $^{-1} \mathrm{~h}^{-1}$ ) was then calculated by linear regression of the number of FLBs per predator cell as a function of incubation time after Sherr et al. (1987).

We estimated the grazing coefficients attributable to red-tide algae, HNFs, and ciliates on bacteria by combining the data on abundances of the predators and bacteria with ingestion rates of the predators on bacteria obtained in the present study. The grazing coefficients $\left(g, \mathrm{~h}^{-1}\right)$ were calculated as follows:

$$
g=\mathrm{CR} \times \mathrm{GC}
$$

where CR ( $\mathrm{ml}$ predator ${ }^{-1} \mathrm{~h}^{-1}$ ) is the clearance rate of a predator on bacteria at a given prey concentration and $\mathrm{GC}$ is the predator concentration (cells ml-1). CRs were calculated as follows:

$$
\mathrm{CR}=\mathrm{IR} / \mathrm{PC}
$$

where IR (cells predator ${ }^{-1} \mathrm{~h}^{-1}$ ) is the ingestion rate of the predator on bacteria and PC (cells ml-1) is the prey concentration. 
Table 1. Water temperature, salinity, and nutrient conditions for incubation of bacteria and their predators during red tides in Korean waters in 2004-2005. Data on nutrients are mean $\pm \mathrm{SE}$

\begin{tabular}{|c|c|c|c|c|c|}
\hline Site & $\begin{array}{c}\text { Date } \\
\text { (dd/mm/yy) }\end{array}$ & $\begin{array}{l}\text { Temp. } \\
\left({ }^{\circ} \mathrm{C}\right)\end{array}$ & $\begin{array}{l}\text { Salinity } \\
\text { (psu) }\end{array}$ & $\begin{array}{c}\mathrm{NO}_{2}+\mathrm{NO}_{3} \\
(\mu \mathrm{M})\end{array}$ & $\begin{array}{l}\mathrm{PO}_{4} \\
(\mu \mathrm{M})\end{array}$ \\
\hline Keum Estuary & $20 / 05 / 05$ & 21.5 & 17.5 & $72.3 \pm 7.0$ & $0.6 \pm 0.2$ \\
\hline Shiwha Bay & $14 / 07 / 05$ & 24.0 & 22.4 & $223.2 \pm 14.1$ & $8.9 \pm 0.0$ \\
\hline Masan Bay & $\begin{array}{l}25 / 12 / 04 \\
26 / 12 / 04 \\
09 / 06 / 05\end{array}$ & $\begin{array}{c}10.1 \\
9.8 \\
23.8\end{array}$ & $\begin{array}{l}30.5 \\
30.6 \\
28.7\end{array}$ & $\begin{array}{l}21.5 \pm 1.8 \\
11.6 \pm 1.4 \\
59.7 \pm 2.4\end{array}$ & $\begin{array}{l}3.0 \pm 0.5) \\
1.1 \pm 0.1 \\
2.2 \pm 0.1\end{array}$ \\
\hline Jinhae Bay & $\begin{array}{l}23 / 06 / 05 \\
24 / 06 / 05 \\
25 / 06 / 05\end{array}$ & $\begin{array}{l}27.4 \\
28.1 \\
28.0\end{array}$ & $\begin{array}{l}30.2 \\
30.8 \\
30.3\end{array}$ & $\begin{array}{l}70.7 \pm 1.4 \\
72.2 \pm 6.7 \\
44.4 \pm 2.7\end{array}$ & $\begin{array}{l}5.1 \pm 0.3 \\
3.9 \pm 0.2 \\
2.6 \pm 0.1\end{array}$ \\
\hline $\begin{array}{r}\text { Yeosu waters }(\text { Stn 1) } \\
(\text { Stn 2) } \\
(\text { Stn 3) }\end{array}$ & $\begin{array}{l}05 / 08 / 05 \\
05 / 08 / 05 \\
05 / 08 / 05\end{array}$ & $\begin{array}{l}23.3 \\
23.9 \\
25.7\end{array}$ & $\begin{array}{l}32.4 \\
32.6 \\
32.4\end{array}$ & $\begin{array}{l}1.0 \pm 0.1 \\
1.2 \pm 0.1 \\
1.1 \pm 0.0\end{array}$ & $\begin{array}{l}1.5 \pm 0.2 \\
1.2 \pm 0.2 \\
1.4 \pm 0.3\end{array}$ \\
\hline
\end{tabular}

Table 2. Volume of FLBs $\left(\mathrm{mm}^{3}\right)$ and bacterial abundance $\left(10^{6}\right.$ cells $\left.\mathrm{ml}^{-1}\right)$. Data are means \pm SE, except those in parentheses (n). Natural: populations of bacteria; FLB: fluorescently labeled bacteria; Abundance ratio: actual initial abundances of FLBs to the abundances of natural populations of bacteria (\%). Ranges of length and width of FLBs used were 0.35-1.22 and 0.61-2.70 $\mu \mathrm{m}$, respectively

\begin{tabular}{|lccccc|}
\hline Site & $\begin{array}{c}\text { Date } \\
(\mathrm{dd} / \mathrm{mm} / \mathrm{yy})\end{array}$ & $\begin{array}{l}\text { Volume } \\
\text { of FLBs }\end{array}$ & Natural & FLB & $\begin{array}{c}\text { Abundance } \\
\text { ratio }\end{array}$ \\
\hline Keum Estuary & $20 / 05 / 05$ & $0.33 \pm 0.03(27)$ & $3.5 \pm 0.2$ & $3.1 \pm 0.3$ & $89 \pm 10(3)$ \\
Shiwha Bay & $14 / 07 / 05$ & $0.37 \pm 0.04(27)$ & $6.5 \pm 0.2$ & $2.5 \pm 0.2$ & $38 \pm 3(3)$ \\
Masan Bay & $25 / 12 / 04$ & $0.39 \pm 0.05(23)$ & $0.8 \pm 0.0$ & $0.3 \pm 0.0$ & $24 \pm 4(9)$ \\
& $26 / 12 / 04$ & & $1.0 \pm 0.0$ & $0.2 \pm 0.0$ & \\
& $09 / 06 / 05$ & & $12.9 \pm 1.1$ & $2.0 \pm 0.1$ & \\
Jinhae Bay & $23 / 06 / 05$ & $0.26 \pm 0.02(23)$ & $6.5 \pm 0.5$ & $2.1 \pm 0.1$ & $21 \pm 3(9)$ \\
& $24 / 06 / 05$ & & $13.0 \pm 0.3$ & $1.6 \pm 0.1$ & \\
Yeosu waters & $25 / 06 / 05$ & & $8.0 \pm 0.7$ & $1.5 \pm 0.1$ & \\
(Stn 1) & $05 / 08 / 05$ & $0.39 \pm 0.05(27)$ & $2.5 \pm 0.2$ & $1.8 \pm 0.2$ & $46 \pm 8(9)$ \\
(Stn 2) & $05 / 08 / 05$ & & $7.2 \pm 1.2$ & $1.7 \pm 0.1$ & \\
(Stn 3) & $05 / 08 / 05$ & & $8.5 \pm 0.5$ & $3.6 \pm 0.8$ & \\
\hline
\end{tabular}

Effects of prey concentration. These experiments were designed to investigate the ingestion rates of Cochlodinium polykrikoides, Heterocapsa rotundata, $H$. triquetra, Prorocentrum minimum, and Heterosigma akashiwo, the most dominant red-tide species during the present field study, on bacteria as a function of prey concentration. Chattonella ovata was also chosen as a target species, because it sometimes forms red-tide patches in some of these field study areas (our unpubl. data).

One or $2 \mathrm{~d}$ prior to this experiment, the bacterial cells that originated from a non-axenic culture of the target redtide alga were fluorescently labeled according to Sherr et al. (1987). The volumes of FLB and ratios of the actual initial abundances of FLB to the abundances of non-FLB bacteria are shown in Table 3. Carbon contents of bacteria were estimated from cell volumes by using the formula: pg $\mathrm{C}$ cell $^{-1}=$ $0.12 V^{0.7}$ (Simon \& Azam 1989, recalculated by Norland 1993), where $V$ is the cell volume $\left(\mu^{3}\right)$ of the bacteria.

A dense culture of each red-tide alga maintained in an $f / 2$ medium in exponential phase was transferred into a 11 PC bottle. Three $1 \mathrm{ml}$ aliquots from the bottle were counted using a compound microscope to determine the cell concentrations of the red-tide alga as described above.

The mean actual initial predator and prey concentrations are shown in Table 3. Triplicate $270 \mathrm{ml} \mathrm{PC}$ experimental bottles (containing mixtures of

Culture of red-tide algae. The red-tide algae used in the present study were grown at $20^{\circ} \mathrm{C}$ in enriched f/2 seawater media (Guillard \& Ryther 1962) without silicate, under a $14 \mathrm{~h}$ light:10 h dark cycle with $30 \mu \mathrm{E}$ $\mathrm{m}^{-2} \mathrm{~s}^{-1}$ of cool white fluorescent light. The mean equivalent spherical diameters (ESDs, mean $\pm \mathrm{SD}$ ) of the algae were measured using an electronic particle counter (Coulter Multisizer II, Coulter Corporation). Carbon contents of the red-tide algae were estimated from cell volumes according to Strathmann (Strathmann 1967). Cultures that were in their exponential growth phase were used for these feeding experiments. The algal cultures were confirmed to be uniprotist cultures without contaminating amoebae or HNFs under a compound microscope at a magnification of $\times 1000$. predator and prey) and triplicate predator control bottles (containing predator only) were also established; $20 \mathrm{ml}$ of $\mathrm{f} / 2$ medium were added to all the bottles, which were then filled to capacity with freshly filtered seawater, capped, placed on a shelf, and then incubated at $20^{\circ} \mathrm{C}$ under continuous illumination of $30 \mu \mathrm{E}$ $\mathrm{m}^{-2} \mathrm{~s}^{-1}$ of cool white fluorescent light. After 1, 5, 10, 20, and $30 \mathrm{~min}$ incubation, $10 \mathrm{ml}$ aliquots were removed from each bottle, transferred into $20 \mathrm{ml}$ vials, and then fixed with borate-buffered formalin (final conc. $=3 \%$ ). The fixed samples were stained using DAPI (final conc. $=1 \mu \mathrm{M}$ ) and then filtered onto 3 - $\mu \mathrm{m}$-pore-sized PC white membrane filters. FLBs inside a red-tide alga were enumerated under an epifluorescent microscope with blue light excitation. The ingestion rates of the red-tide alga on bacteria were determined as de- 
Table 3. Volume of FLBs $\left(\mu^{3}\right.$ ), abundance ratios (actual initial abundances of FLBs to the abundances of non-FLB bacteria, $\%)$, and mean actual initial concentrations of predator and prey. Data are means \pm SE, except those in parentheses (n)

\begin{tabular}{|c|c|c|c|c|c|c|}
\hline \multirow[t]{3}{*}{ Red tide alga } & \multirow[t]{3}{*}{ Volume } & \multirow{3}{*}{$\begin{array}{c}\text { Abundance } \\
\text { ratios }\end{array}$} & \multicolumn{4}{|c|}{ Concentration $\left(\times 10^{4}\right.$ cells $\left.\mathrm{ml}^{-1}\right)$} \\
\hline & & & \multicolumn{2}{|c|}{ Predator } & \multicolumn{2}{|c|}{ Prey } \\
\hline & & & Min. & Max. & Min. & Max. \\
\hline Chattonella ovata & $0.52 \pm 0.09(23)$ & $28 \pm 9(15)$ & $0.100 \pm 0.02$ & $0.241 \pm 0.009(3)$ & $38 \pm 4.1(3)$ & $570 \pm 130(3)$ \\
\hline Cochlodinium polykrikoides & $0.18 \pm 0.02(27)$ & $19 \pm 4(15)$ & $0.047 \pm 0.004$ & $0.227 \pm 0.005$ & $55 \pm 2.8(3)$ & $1300 \pm 210$ \\
\hline Heterocapsa rotundata & $0.32 \pm 0.04(22)$ & $17 \pm 5(18)$ & $0.234 \pm 0.015$ & $0.406 \pm 0.024$ & $65 \pm 4.8(3)$ & $2100 \pm 79$ \\
\hline Heterocapsa triquetra & $0.35 \pm 0.04(22)$ & $38 \pm 12(18)$ & $0.200 \pm 0.002$ & $0.485 \pm 0.033$ & $64 \pm 0.7(3)$ & $2300 \pm 32(3)$ \\
\hline Heterosigma akashiwo & $0.30 \pm 0.03$ & $11 \pm 3(18)$ & $0.221 \pm 0.013$ & $0.781 \pm 0.146$ & $95 \pm 6.1(3)$ & $8500 \pm 99(3)$ \\
\hline Prorocentrum minimum & $0.48 \pm 0.09(22)$ & $17 \pm 3(21)$ & $0.066 \pm 0.005$ & $0.128 \pm 0.003(3)$ & $33 \pm 0.85(3)$ & $900 \pm 14$ \\
\hline
\end{tabular}

scribed above. Additionally, at the beginning of the experiment, a $1 \mathrm{ml}$ fixed aliquot was stained with DAPI and then filtered onto 0.2- $\mu \mathrm{m}$-pore-sized PC black membrane filters. Bacteria (both FLB and non-FLB) outside the red-tide algal cells were also enumerated under an epifluorescent microscope with UV light excitation for non-FLBs and blue light excitation for FLBs. After subsampling, the bottles were capped, placed on a shelf, and incubated again as described above.

All ingestion rate data were fitted to a Michaelis-Menten equation:

$$
\mathrm{IR}=\frac{I_{\max }}{K_{\mathrm{IR}}(x)}
$$

where $I_{\max }$ is the maximum ingestion rate (cells predator $^{-1} \mathrm{~h}^{-1}$ ), $\mathrm{x}$ is prey concentration (cells $\mathrm{ml}^{-1}$ ), and $K_{\mathrm{IR}}$ is the prey concentration sustaining $1 / 2 I_{\text {max }}$.

Two to $6 \mathrm{ml}$ aliquots fixed with formalin at the end of the experiment were stained using DAPI (final conc. = $1 \mu \mathrm{M}$ ) and then filtered onto 3- $\mu \mathrm{m}$-pore-sized, $25 \mathrm{~mm}$ PC white membrane filters. The concentrated cells on the membranes were observed under a confocal laser scanning microscope (CLSM, Carl Zeiss-LSM510) at a magnification of $\times 1000$ by scanning the algal body at consecutive intervals of 1 to $2 \mu \mathrm{m}$ along the $z$-axis. Pictures showing ingested bacterial cells inside each algal predator cell were taken using digital cameras on a confocal laser scanning microscope and/or an epifluorescent microscope at a magnification of $\times 1000$. Additionally 8 red-tide algal species (Akashiwo sanguinea, Alexandrium catenella, Amphidinium carterae, Gonyaulax polygramma, Gymnodinium catenatum, G. impudicum, Lingulodinium polyedrum, and Scrippsiella trochoidea) were observed to investigate whether or not each algal species was able to feed on marine bacteria. Approximately $10^{8}$ FLB cells were placed into a $270 \mathrm{ml}$ PC bottle for each target alga. After 10, 20, and $30 \mathrm{~min}$ incubation, $10 \mathrm{ml}$ aliquots were removed from the bottle, transferred into $20 \mathrm{ml}$ vials, and then fixed with formalin. The fixed samples were stained using DAPI, filtered, and then the concentrated cells on the membranes were observed under a confocal laser scanning microscope as described above.

\section{RESULTS}

Feeding by protistan predators on marine bacteria in Korean waters

We measured the ingestion rates of natural populations of co-occurring red-tide algae, HNFs, and ciliates $(<30 \mu \mathrm{m}$ in cell length) on natural populations of marine bacteria during red tides dominated by the dinoflagellate Heterocapsa rotundata in the Keum River estuary (20 May 2005); the dinoflagellate Prorocentrum minimum in Shiwha Bay (14 July 2005); $P$. minimum and $H$. triquetra (25 to 26 December 2004), the raphidophyte Heterosigma akashiwo, and the euglenophyte Eutreptiella sp. (9 June 2005) in Masan Bay; P. minimum and H. akashiwo in Jinhae Bay (23 to 25 June 2005); and the dinoflagellate Cochlodinium polykrikoides in the open coastal waters off Yeosu (5 August 2005; Table 4).

During all field experiments, the water temperature ranged (mean $\pm \mathrm{SE}$, $\mathrm{n}$ ) from 9.8 to $28.1^{\circ} \mathrm{C}(22.3 \pm 2.0$, 11), while the salinity ranged from 17.5 to $32.6 \mathrm{psu}$ $(28.9 \pm 1.5,11$; Table 1$)$. The range (mean $\pm \mathrm{SE}, \mathrm{n})$ of the nitrate plus nitrite concentration was 1.0 to $223.2 \mu \mathrm{M}(52.6 \pm 19.6,11)$, while that of the phosphate concentration was 0.6 to $9.0 \mu \mathrm{M}(2.9 \pm 0.8,11)$.

During the field experiments, the range of the mean $( \pm \mathrm{SE}, \mathrm{n}=3$ to 12$)$ abundances of bacteria was from $0.8( \pm 0.01)$ to $13.0( \pm 1.1) \times 10^{6}$ cells ml ${ }^{-1}$ (Table 2$)$. The minimum bacterial abundance was observed in Masan Bay in December 2004, while the maximum bacterial abundance was observed at the same location in June 2005 (Table 2). The mean abundances of Heterocapsa rotundata and/or $H$. triquetra, Prorocentrum minimum and/or $P$. triestinum, Heterosigma akashiwo, and Cochlodinium polykrikoides ranged from 200-37640, 
Table 4. Ingestion of marine bacteria by red-tide algae, heterotrophic nanoflagellates (HNFs), and ciliates $(<30 \mu m)$ in Korean waters during red tides in 2004-2005. Data are mean \pm SE

\begin{tabular}{|c|c|c|c|c|c|c|}
\hline Location & $\begin{array}{c}\text { Date } \\
(\mathrm{dd} / \mathrm{mm} / \mathrm{yy})\end{array}$ & Predator & $\begin{array}{l}\text { Abundance } \\
\text { (ind. } \mathrm{ml}^{-1} \text { ) }\end{array}$ & $\begin{array}{c}\text { Ingestion } \\
\text { rate } \\
\text { (cells ind. } .^{-1} \mathrm{~h}^{-1} \text { ) }\end{array}$ & $\begin{array}{l}\text { Clearance } \\
\text { rate } \\
\left(\mathrm{nl} \text { ind. } .^{-1} \mathrm{~h}^{-1}\right)\end{array}$ & $\begin{array}{l}\text { Grazing } \\
\text { coefficient } \\
\left(\mathrm{d}^{-1}\right)\end{array}$ \\
\hline \multirow[t]{4}{*}{ Keum estuary } & \multirow[t]{4}{*}{$20 / 05 / 05$} & Heterocapsa rotundata & $37640 \pm 1380$ & $2.2 \pm 0.1$ & $0.6 \pm 0.0$ & $0.569 \pm 0.02$ \\
\hline & & Heterocapsa triquetra & $8410 \pm 290$ & $2.6 \pm 0.4$ & $0.7 \pm 0.1$ & $0.151 \pm 0.024$ \\
\hline & & HNFs & $2800 \pm 330$ & $6.3 \pm 3.9$ & $1.8 \pm 1.1$ & $0.120 \pm 0.075$ \\
\hline & & Ciliates & $4.2 \pm 0.5$ & $19 \pm 4$ & $5.4 \pm 1.1$ & $0.001 \pm 0.000$ \\
\hline \multirow[t]{4}{*}{ Shiwha Bay } & \multirow[t]{4}{*}{$14 / 07 / 05$} & Prorocentrum triestinum & $20650 \pm 970$ & $7.0 \pm 0.9$ & $1.1 \pm 0.1$ & $0.498 \pm 0.097$ \\
\hline & & Heterosigma akashiwo & $550 \pm 60$ & $9.0 \pm 1.2$ & $1.4 \pm 0.2$ & $0.020 \pm 0.003$ \\
\hline & & HNFs & $1400 \pm 320$ & $7.1 \pm 1.9$ & $1.1 \pm 0.3$ & $0.046 \pm 0.006$ \\
\hline & & Ciliates & $6.0 \pm 0.6$ & $107 \pm 43$ & $17 \pm 7$ & $0.003 \pm 0.002$ \\
\hline \multirow{12}{*}{ Masan Bay } & \multirow{4}{*}{$25 / 12 / 04$} & Prorocentrum minimum & $3760 \pm 130$ & $2.0 \pm 0.5$ & $2.7 \pm 0.6$ & $0.238 \pm 0.100$ \\
\hline & & Heterocapsa triquetra & $280 \pm 10$ & $3.5 \pm 0.7$ & $4.6 \pm 0.9$ & $0.024 \pm 0.001$ \\
\hline & & HNFs & $420 \pm 40$ & $1.7 \pm 0.5$ & $2.2 \pm 0.7$ & $0.029 \pm 0.003$ \\
\hline & & Ciliates & $1.8 \pm 0.3$ & $43 \pm 7$ & $57 \pm 9$ & $0.002 \pm 0.001$ \\
\hline & \multirow[t]{4}{*}{$26 / 12 / 04$} & Prorocentrum minimum & $8480 \pm 550$ & $2.8 \pm 1.2$ & $2.7 \pm 1.1$ & $0.702 \pm 0.305$ \\
\hline & & Heterocapsa triquetra & $200 \pm 30$ & $3.5 \pm 1.0$ & $3.4 \pm 1.0$ & $0.019 \pm 0.007$ \\
\hline & & HNFs & $760 \pm 140$ & $2.2 \pm 0.4$ & $2.1 \pm 0.4$ & $0.036 \pm 0.013$ \\
\hline & & Ciliates & $1.3 \pm 0.3$ & $219 \pm 91$ & $211 \pm 88$ & $0.008 \pm 0.004$ \\
\hline & \multirow[t]{4}{*}{ 09/06/05 } & Heterosigma akashiwo & $3530 \pm 290$ & $8.5 \pm 1.5$ & $0.7 \pm 0.1$ & $0.046 \pm 0.005$ \\
\hline & & Eutreptiella sp. & $1530 \pm 270$ & $13.2 \pm 2.1$ & $1.0 \pm 0.2$ & $0.039 \pm 0.010$ \\
\hline & & HNFs & $2560 \pm 40$ & $15.4 \pm 2.9$ & $1.2 \pm 0.2$ & $0.086 \pm 0.006$ \\
\hline & & Ciliates & $270 \pm 60$ & $473 \pm 181$ & $36 \pm 14$ & $0.174 \pm 0.115$ \\
\hline \multirow[t]{12}{*}{ Jinhae Bay } & \multirow[t]{4}{*}{$23 / 06 / 05$} & Prorocentrum minimum & $18290 \pm 1410$ & $3.9 \pm 0.9$ & $0.6 \pm 0.1$ & $0.260 \pm 0.063$ \\
\hline & & Heterosigma akashiwo & $16980 \pm 770$ & $2.7 \pm 0.1$ & $0.4 \pm 0.0$ & $0.166 \pm 0.005$ \\
\hline & & HNFs & $970 \pm 30$ & $7.6 \pm 0.4$ & $1.2 \pm 0.1$ & $0.027 \pm 0.001$ \\
\hline & & Ciliates & $24 \pm 7$ & $150 \pm 44$ & $23 \pm 7$ & $0.013 \pm 0.004$ \\
\hline & \multirow[t]{4}{*}{$24 / 06 / 05$} & Heterosigma akashiwo & $59670 \pm 2430$ & $7.8 \pm 1.5$ & $0.6 \pm 0.1$ & $0.857 \pm 0.166$ \\
\hline & & Prorocentrum minimum & $30120 \pm 760$ & $15.3 \pm 5.3$ & $1.2 \pm 0.4$ & $0.850 \pm 0.297$ \\
\hline & & HNFs & $2420 \pm 440$ & $38 \pm 2$ & $2.9 \pm 0.1$ & $0.169 \pm 0.008$ \\
\hline & & Ciliates & $970 \pm 105$ & $137 \pm 40$ & $11 \pm 3$ & $0.245 \pm 0.071$ \\
\hline & \multirow[t]{4}{*}{$25 / 06 / 05$} & Heterosigma akashiwo & $39510 \pm 4880$ & $4.9 \pm 1.4$ & $0.6 \pm 0.2$ & $0.581 \pm 0.168$ \\
\hline & & Prorocentrum minimum & $7440 \pm 900$ & $5.1 \pm 0.2$ & $0.6 \pm 0.0$ & $0.113 \pm 0.003$ \\
\hline & & HNFs & $600 \pm 30$ & $6.4 \pm 1.9$ & $0.8 \pm 0.2$ & $0.011 \pm 0.003$ \\
\hline & & Ciliates & $1380 \pm 140$ & $144 \pm 29$ & $18 \pm 4$ & $0.596 \pm 0.120$ \\
\hline \multirow{9}{*}{ Yeosu waters (Stn 1) } & \multirow[t]{3}{*}{ 05/08/05 } & Cochlodinium polykrikoides & $1300 \pm 50$ & $2.9 \pm 0.5$ & $1.2 \pm 0.2$ & $0.043 \pm 0.003$ \\
\hline & & HNFs & $2570 \pm 410$ & $4.1 \pm 0.3$ & $1.7 \pm 0.1$ & $0.098 \pm 0.012$ \\
\hline & & Ciliates & $5.4 \pm 0.5$ & $64 \pm 1$ & $26 \pm 1$ & $0.003 \pm 0.000$ \\
\hline & \multirow[t]{3}{*}{ 05/08/05 } & Cochlodinium polykrikoides & $1520 \pm 160$ & $7.9 \pm 1.1$ & $1.1 \pm 0.2$ & $0.040 \pm 0.010$ \\
\hline & & HNFs & $7710 \pm 990$ & $6.4 \pm 0.6)$ & $0.9 \pm 0.1$ & $0.174 \pm 0.017$ \\
\hline & & Ciliates & $33.8 \pm 3.5$ & $159 \pm 26)$ & $22 \pm 4$ & $0.017 \pm 0.005$ \\
\hline & \multirow[t]{3}{*}{ 05/08/05 } & Cochlodinium polykrikoides & $2330 \pm 390$ & $9.3 \pm 0.9$ & $1.1 \pm 0.1$ & $0.067 \pm 0.002$ \\
\hline & & HNFs & $4870 \pm 150$ & $6.3 \pm 0.8$ & $0.7 \pm 0.1$ & $0.076 \pm 0.005$ \\
\hline & & Ciliates & $3.6 \pm 0.4$ & $323 \pm 93$ & $38 \pm 11$ & $0.002 \pm 0.000$ \\
\hline
\end{tabular}

3760-30 120, 550-59670, and 1300-2330 cells $\mathrm{ml}^{-1}$, respectively ( $\mathrm{n}=3$, see Table 4 for SEs). The mean abundances of HNFs ranged from 420 to 7710 cells $\mathrm{ml}^{-1}(\mathrm{n}=3$, see Table 4 for SEs), while that of ciliates ranged from 1 to 1380 cells ml $^{-1}$ ( $\mathrm{n}=3$ to 11 , see Table 4 for SEs). The HNFs were most abundant during the red tides dominated by C. polykrikoides in the open coastal waters off Yeosu in August 2005. On the other hand, the ciliates were abundant during the red tide dominated by $P$. minimum and H. akashiwo in Jinhae Bay in June 2005.

During field experiments, the dominant red-tide algae Cochlodinium polykrikoides, Eutreptiella sp., Heterocapsa rotundata, $H$. triquetra, Heterosigma akashiwo,
Prorocentrum minimum, and $P$. triestinum were observed to ingest FLBs (Fig. 2). The red-tide dinoflagellates $P$. donghaiense and $P$. micans were also observed to contain bacterial cells inside their protoplasm, even though bacterial abundances were relatively low. No green inclusions were observed inside the protoplasm of the predators in the control bottles (without FLB).

During field experiments the mean $( \pm \mathrm{SE}, \mathrm{n})$ of the ingestion rates of all dominant red-tide algae on natural populations of bacteria obtained in the present study was 6.1 bacteria alga $^{-1} \mathrm{~h}^{-1}( \pm 0.6,49$; range $=1.2$ to 20.6 bacteria alga ${ }^{-1} \mathrm{~h}^{-1}$; Table 4$)$. The mean ingestion rates (range, mean $\pm \mathrm{SE}, \mathrm{n}$ ) of natural populations of bacteria 

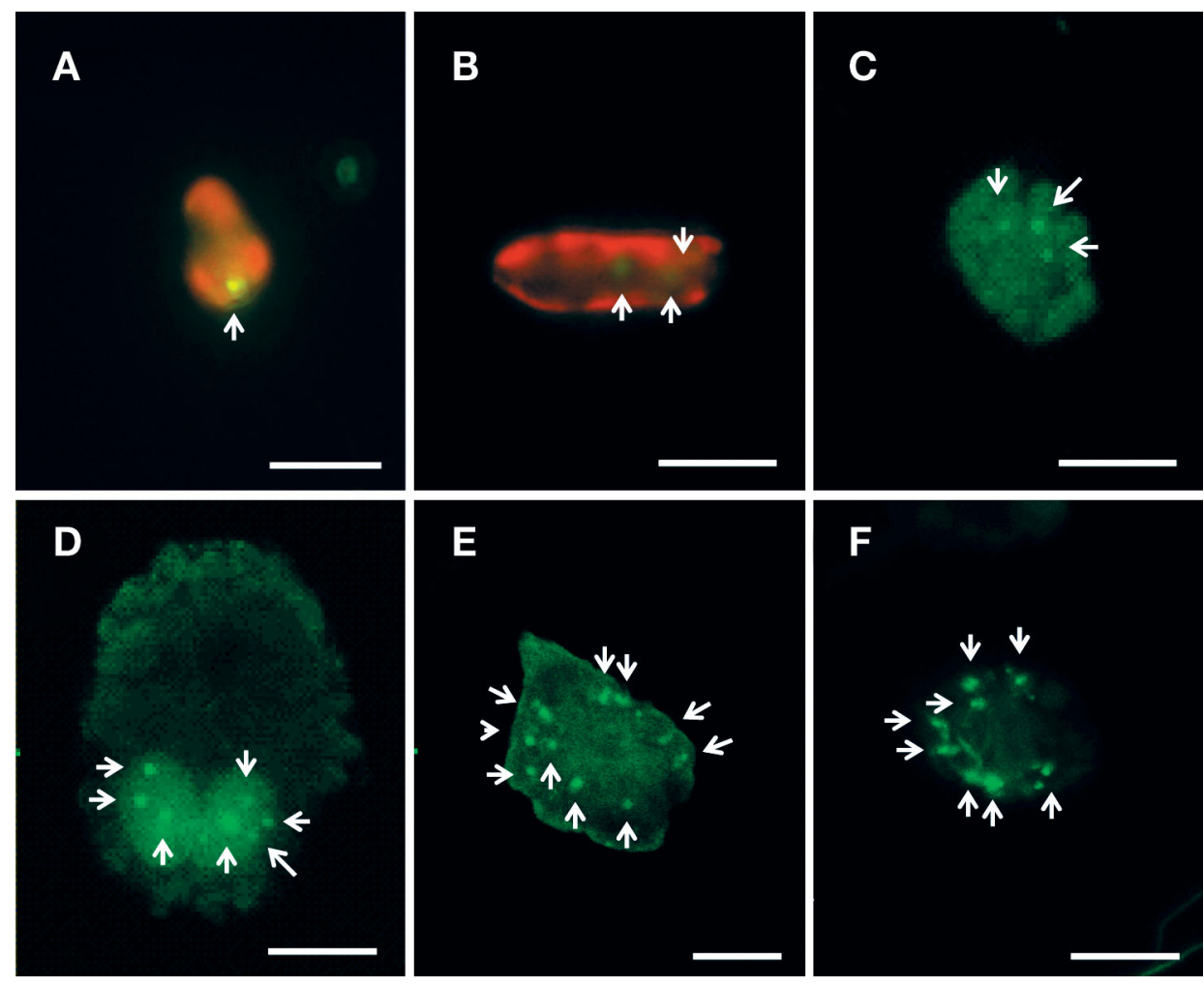

Fig. 2. Feeding by red-tide algae on bacteria: (A) Heterocapsa rotundata, (B) Prorocentrum donghaiense, (C) Heterosigma akashiwo, (D) Chattonella ovata, (E) Gonyaulax polygramma, and (F) P. minimum. Scale bars: 10 um. Arrows: ingested prey cells, which are fluorescently labeled bacteria. Panels are photographs taken using $(\mathrm{A}, \mathrm{B})$ an epifluorescent microscope, $(\mathrm{C}-\mathrm{F})$ a confocal laser scanning microscope

by Heterocapsa rotundata and/or $H$. triquetra (2.1 to 5.6 bacteria alga $\left.{ }^{-1} \mathrm{~h}^{-1}, 3.1 \pm 0.4,10\right)$, Prorocentrum minimum and/or $P$. triestinum (1.2 to 20.6 bacteria alga ${ }^{-1} \mathrm{~h}^{-1}, 5.6 \pm$ $1.3,15)$, Heterosigma akashiwo (2.6 to 11.4 bacteria $\left.\operatorname{alga}^{-1} \mathrm{~h}^{-1}, 6.9 \pm 0.9,12\right)$, Cochlodinium polykrikoides $(2.0$ to 10.5 bacteria alga $\left.^{-1} \mathrm{~h}^{-1}, 6.7 \pm 1.1,9\right)$, and Eutreptiella sp. (10.0 to 17.3 bacteria alga $\left.{ }^{-1} \mathrm{~h}^{-1}, 13.2 \pm 2.1,3\right)$ were significantly different ( $\mathrm{p}<0.01$, ANOVA). The mean ingestion rate of $H$. rotundata and/or $H$. triquetra was significantly lower than that of the other red-tide algae $(\mathrm{p}<$ 0.01, 1-tailed $t$-test), except $P$. minimum and/or $P$. triestinum ( $p>0.05)$, while the mean ingestion rate of Eutreptiella sp. was significantly higher than that of the other red-tide algae $(\mathrm{p}<0.05$ to 0.001$)$. However, the mean ingestion rates of $P$. minimum and/or $P$. triestinum, H. akashiwo, and C. polykrikoides were not significantly different from one another ( $\mathrm{p}>0.1,1$-tailed $t$-test).

The mean ingestion rates (range, mean $\pm \mathrm{SE}, \mathrm{n}$ ) of all HNFs $\left(0.7\right.$ to 39.4 bacteria $\left.\mathrm{HNF}^{-1} \mathrm{~h}^{-1}, 8.5 \pm 1.7,29\right)$ and all ciliates on natural populations of bacteria obtained in the present study (15 to 713 bacteria ciliate ${ }^{-1} \mathrm{~h}^{-1}$, $175 \pm 32$, 29) were significantly higher than the mean ingestion rate of all red-tide algae ( $p<0.05$ for HNFs and $\mathrm{p}<0.005$ for ciliates, 1 -tailed $t$-test).
During field experiments the mean $( \pm S E, n)$ clearance rate of all red-tide algae on natural populations of bacteria obtained in the present study was $1.5 \mathrm{nl}$ alga $^{-1}$ $\mathrm{h}^{-1}\left( \pm 0.2,49\right.$; range $=0.4$ to $6.4 \mathrm{nl}$ alga $^{-1} \mathrm{~h}^{-1} ;$ Table 4$)$. The clearance rates (range, mean $\pm \mathrm{SE}, \mathrm{n}$ ) of Heterocapsa rotundata and/or $H$. triquetra $\left(0.6\right.$ to $6.4 \mathrm{nl}_{\mathrm{alga}^{-1}}$ $\left.\mathrm{h}^{-1}, 2.7 \pm 0.7,10\right)$, Prorocentrum minimum and/or $P$. triestinum (0.4 to $\left.5.0 \mathrm{nl} \operatorname{alga}^{-1} \mathrm{~h}^{-1}, 1.6 \pm 0.3,15\right)$, Heterosigma akashiwo $\left(0.4\right.$ to $1.8 \mathrm{nl}$ alga $^{-1} \mathrm{~h}^{-1}, 0.8 \pm 0.1$, 12), Cochlodinium polykrikoides (0.8 to $1.5 \mathrm{nl} \mathrm{alga}^{-1}$ $\left.\mathrm{h}^{-1}, 1.1 \pm 0.1,9\right)$, and Eutreptiella sp. (0.8 to $1.3 \mathrm{nl} \mathrm{alga}^{-1}$ $\mathrm{h}^{-1}, 1.0 \pm 0.2,3$ ) on natural populations of bacteria were significantly different ( $\mathrm{p}<0.05$, ANOVA). The mean clearance rate of $H$. rotundata and/or $H$. triquetra was significantly greater than that of $H$. akashiwo $(\mathrm{p}<$ 0.005 , 1-tailed $t$-test), or C. polykrikoides ( $\mathrm{p}<0.05$ ), while it was not significantly greater than that of $P$. minimum and/or $P$. triestinum $(\mathrm{p}>0.1)$.

The mean clearance rate (range, mean $\pm \mathrm{SE}, \mathrm{n}$ ) of all HNFs $\left(0.5\right.$ to $\left.3.1 \mathrm{nl} \mathrm{HNF}^{-1} \mathrm{~h}^{-1}, 1.5 \pm 0.2,29\right)$ was not significantly higher than that of all red-tide algae ( $\mathrm{p}>0.1$ 1 -tailed $t$-test), while that of all ciliates (4 to $385 \mathrm{nl}$ ciliate $\left.^{-1} \mathrm{~h}^{-1}, 46 \pm 13,29\right)$ was significantly higher than that of all red-tide algae $(p<0.005$; Table 4$)$. 
The mean (range, mean $\pm \mathrm{SE}, \mathrm{n}$ ) grazing coefficient of the natural population of bacteria attributable to all redtide algae during the red tides $\left(0.012\right.$ to $1.146 \mathrm{~d}^{-1}, 0.244 \pm$ $0.044,49)$ was significantly greater than that of all HNFs $\left(0.008\right.$ to $\left.0.196 \mathrm{~d}^{-1}, 0.077 \pm 0.011,29\right)$ or all ciliates $(0.000$ to $\left.0.716 \mathrm{~d}^{-1}, 0.087 \pm 0.033,29\right)(\mathrm{p}<0.005$ for both HNFs and ciliates, 1 -tailed $t$-test; Table 4 ). However, the mean grazing coefficient attributable to all HNFs was not significantly different from that attributable to all ciliates ( $\mathrm{p}>0.1,2$-tailed $t$-test).

Data from this study show that the ingestion rates of the dominant red-tide algae $(\mathrm{n}=49)$, HNFs $(\mathrm{n}=29)$, and ciliates $(n=29)$ on the natural populations of bacteria were positively correlated with the bacterial concentrations ( $\mathrm{p}<0.001$ for red-tide algae and HNFs and $\mathrm{p}<0.05$ for ciliates, linear regression ANOVA) in Korean waters (Fig. 3). However, the ingestion rates of the dominant red-tide algae $(\mathrm{n}=49)$ showed no clear correlation with nitrate plus nitrite or phosphate concentrations ( $p>0.1$; Fig. 4).

\section{Effects of prey concentration}

With increasing initial prey concentration, the ingestion rates of Heterocapsa rotundata, Heterosigma akashiwo, Prorocentrum minimum, H. triquetra, Cochlo-

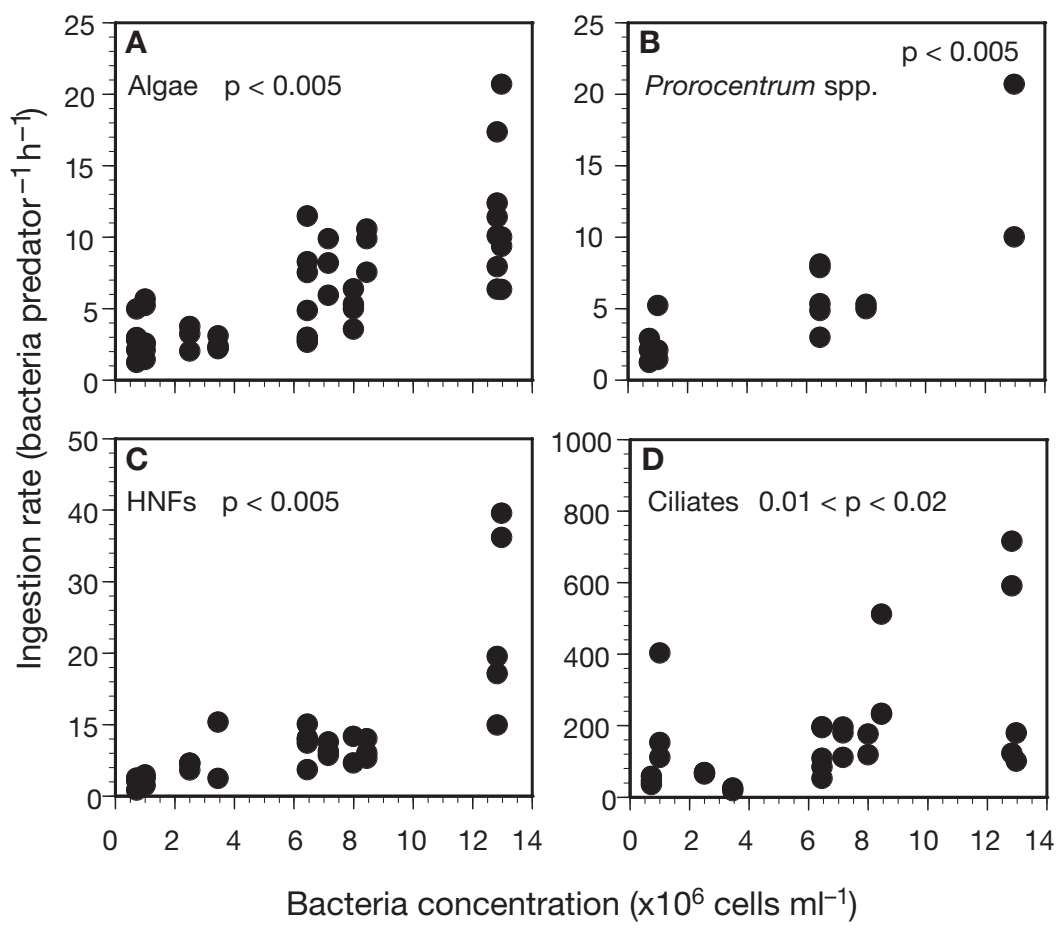

Fig. 3. Ingestion rates (IR, cells predator ${ }^{-1} \mathrm{~h}^{-1}$ ) of: (A) all red-tide algae, (B) Prorocentrum minimum/P. triestinum, $(\mathrm{C})$ heterotrophic nanoflagellates (HNFs), and (D) ciliates, on natural populations of marine bacteria as a function of bacterial concentration, as in Tables $2 \& 4$. Note different scales on $y$-axes dinium polykrikoides, and Chattonella ovata on bacteria increased rapidly at the prey concentrations of ca. 5 to $10 \times 10^{6}$ cells ml $^{-1}$, and increased slowly or reached saturation at higher prey concentrations (Fig. 5, Table 5). When the data were fitted to Eq. (3), the maximum ingestion rates of red-tide algae on bacteria were 12.2 cells alga ${ }^{-1} \mathrm{~h}^{-1}$ for $H$. rotundata, 11.7 for $H$. akashiwo, 21.9 for $P$. minimum, 6.0 for $H$. triquetra, 17.4 for C. polykrikoides, and 24.5 for C. ovata (Table 5).

The percentage of daily acquired carbon from bacteria to the body carbon of the smallest alga, Heterocapsa rotundata, was the greatest $(76.1 \%)$, while that of the largest alga, Chattonella ovata, was the smallest (1.4\%; Table 5).

The maximum clearance rates of bacteria by red-tide algae were $1.4 \mathrm{nl}$ alga $^{-1} \mathrm{~h}^{-1}$ for Heterocapsa rotundata, 2.6 for Heterosigma akashiwo, 2.3 for Prorocentrum minimum, 1.3 for $H$. triquetra, 1.0 for Cochlodinium polykrikoides, and 4.5 for Chattonella ovata, respectively (Table 5). The maximum volume-specific clearance rates were $1.4 \times 10^{4} \mathrm{~h}^{-1}$ for $H$. rotundata, $3.3 \times 10^{3}$ for $H$. akashiwo, $2.5 \times 10^{3}$ for $P$. minimum, 730 for $H$. triquetra, 110 for C. polykrikoides, and 130 for C. ovata, respectively.

Besides Cochlodinium polykrikoides, Heterocapsa rotundata, $H$. triquetra, Prorocentrum donghaiense, P. micans, P. minimum, P. triestinum, Chattonella ovata, and Heterosigma akashiwo, all red-tide algae tested in the present study (Akashiwo sanguinea, Alexandrium catenella, Amphidinium carterae, Gonyaulax polygramma, Gymnodinium catenatum, Gymnodinium impudicum, Lingulodinium polyedrum, and Scrippsiella trochoidea) were observed to contain FLBs inside the protoplasm (under confocal laser scanning microscope or epifluorescent microscope; Fig. 2). The ingested FLB cells were found aggregated in 1 or 2 areas of the protoplasm of some C. ovata cells, as shown in Fig. 2D, but they were widely distributed in other $C$. ovata cells $(\mathrm{n}=30)$.

\section{DISCUSSION}

\section{Feeding by protistan predators on marine bacteria in Korean waters}

The present study simultaneously measured the ingestion rates of the natural populations of marine bacteria by the dominant red-tide algae, HNFs, and ciliates in several locations of Korean waters and compared the calculated grazing impacts of 

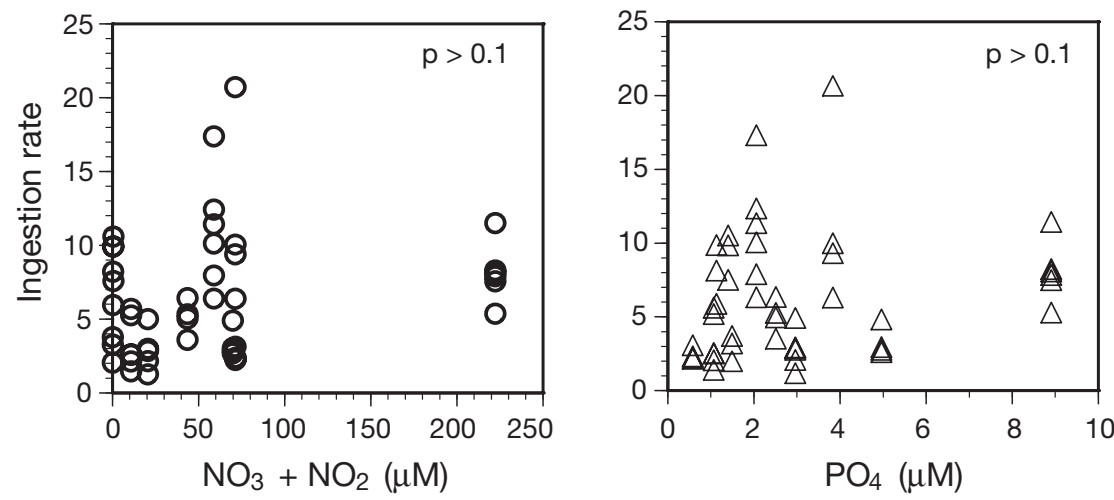

Fig. 4. Ingestion rates (IR, cells predator ${ }^{-1} \mathrm{~h}^{-1}$ ) of all red-tide algae on natural populations of marine bacteria as a function of nitrate plus nitrite $\left(\mathrm{NO}_{3}+\mathrm{NO}_{2}\right)$ and phosphate $\left(\mathrm{PO}_{4}\right)$ concentrations, as in Tables $1 \& 4$

these 3 protistan predator groups. So far, there have been many studies comparing the ingestion rates and/or grazing impact of HNFs and ciliates on marine bacteria (Epstein 1997, Posch et al. 1999, Boenigk \& Novarino 2004), but no studies have compared these parameters among co-occurring red-tide algae, HNFs, and ciliates.

Based on comparison of the grazing coefficients on the natural populations of marine bacteria attributable to the dominant red-tide algae, HNFs, and ciliates during redtides, the results of the present study suggest that the red-tide algae Heterocapsa rotundata/H. triquetra, Heterosigma akashiwo, Prorocentrum minimum/P. triestinum, and Cochlodinium polykrikoides are the most ( 7 of 11 field experiments) or the second most (4 of 11) effective protistan predators of marine bacteria in Korean waters. The combined grazing coefficients of the natural populations of marine bacteria attributable to the dominant red-tide algae (1 or 2 species for each field experiment; see Table 4) ranged (mean $\pm \mathrm{SE}, \mathrm{n}$ ) from 0.04 to $1.71 \mathrm{~d}^{-1}(0.48 \pm 0.27,11)$ (i.e. 4 to $82 \%$ [mean $38 \%$ ] of the bacterial populations were removed by redtide algal populations in $1 \mathrm{~d}$ ). Therefore, with the exception of C. polykrikoides, red-tide algae can have considerable potential grazing impact on the populations of marine bacteria in Korean waters during red-tides; thus, we must consider the grazing by red-tide algae on bacteria when estimating the total mortality rates of marine bacteria due to grazing. However, during the absence of red tides, the abundances of red-tide algae were $<10 \%$ of those measured in the present study (our unpubl. data). Under these circumstances, the calculated grazing impact of red-tide algae on populations of marine bacteria could be negligible.

All dominating red-tide algae in the study areas were able to feed on bacteria when nitrate plus nitrite and phosphate concentrations were high ( 1 to $223 \mu \mathrm{M}$ and 0.6 to $9.0 \mu \mathrm{M}$, respectively). Also, the ingestion rates of the dominant red-tide algae on natural populations of bacteria were not affected by nitrate plus nitrite or phosphate concentrations. Nygaard \& Tobiesen (1993) reported that Heterosigma akashiwo did not ingest bacteria at high phosphate concentrations (batch cultures, 0.3 to $1.6 \mu \mathrm{M}$ ), while our data show that $H$. akashiwo ingested bacteria when the phosphate concentrations were 2.2 to $3.9 \mu \mathrm{M}$. This feeding by $H$. akashiwo on bacteria when phosphate concentrations were high was confirmed in our laboratory experiment. Different strains of this red-tide alga may yield such contrasting results. Different methods might also cause this discrepancy; Nygaard \& Tobiesen (1993) used only radioactively labeled bacteria for the experiments on the uptake of bacteria by H. akashiwo and dinoflagellate predators, while we used FLBs that were directly observed under an epifluorescent microscope. It is therefore worthwhile to explore the effects of phosphate concentrations on the feeding by diverse strains of $H$. akashiwo on marine bacteria.

The ingestion rates of HNFs on natural populations of bacteria in Korean waters ( 1 to 39 cells $\mathrm{HNF}^{-1} \mathrm{~h}^{-1}$ ) are comparable to those measured in Chesapeake Bay (4 to 25 cells $\mathrm{HNF}^{-1} \mathrm{~h}^{-1}$; McManus \& Fuhrman 1988), on the shelf off Cape Hatteras, North Carolina (5 to 65 cells $\mathrm{HNF}^{-1} \mathrm{~h}^{-1}$; Sherr et al. 2002), and in the Weddell Sea (undetected to 67 cells $\mathrm{HNF}^{-1} \mathrm{~h}^{-1}$; Vaque et al. 2002). The ingestion rates of ciliates on the natural populations of bacteria in Korean waters (15 to 713 cells ciliate ${ }^{-1} \mathrm{~h}^{-1}$ ) were higher than those measured in Tidal creek (1 to 200 cells ciliate ${ }^{-1} \mathrm{~h}^{-1}$; Albright et al. 1987). However, these rates were comparable to those in Mejillonse Bay (270 to 663 cells ciliate ${ }^{-1} \mathrm{~h}^{-1}$; Vargas \& Gonzalez 2004). Therefore, the ingestion rates of HNFs and ciliates measured in the present study were comparable to those in the literature.

There is a possibility that bacteria are ingested by HNFs and these HNFs were, in turn, ingested by redtide algae in these field experiments, although the incubation time was $30 \mathrm{~min}$. Some large red-tide algae were observed to ingest HNFs (our unpubl. data), but an additional intensive study is necessary to quantify the importance of this 2-step process.

\section{Prey concentration effects on ingestion rates}

Prior to the present study, there had been no study on the functional responses by red-tide algae on marine bacteria. In general, with increasing bacterial concentration, the ingestion rates of red-tide algae increased rapidly at the prey concentrations of ca. 5 to $10 \times 10^{6}$ cells 

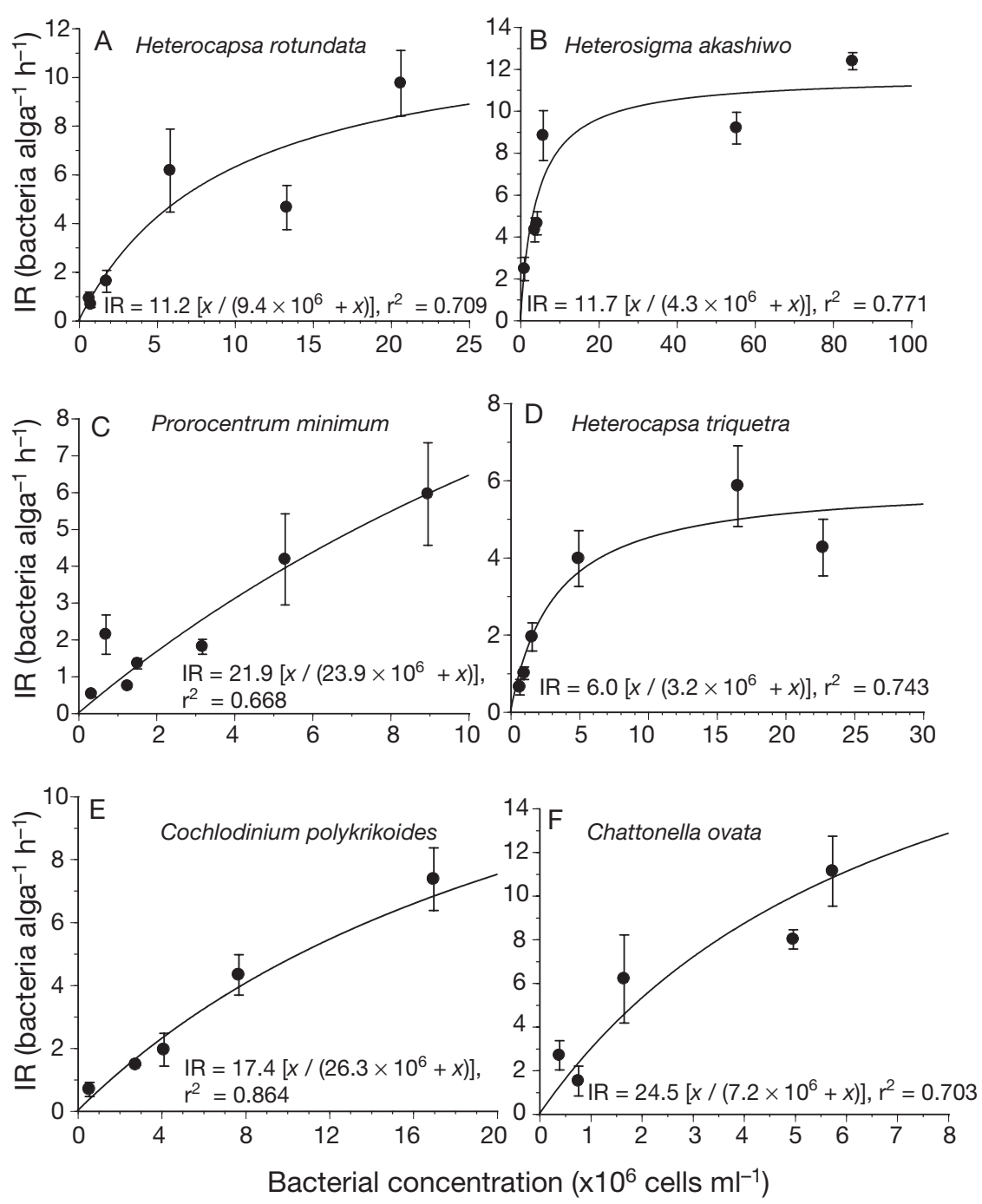

Fig. 5. Ingestion rates (IR, cells alga $\mathrm{a}^{-1} \mathrm{~h}^{-1}$ ) of red-tide algae on bacteria as a function of the initial prey concentration (cells ml ${ }^{-1}, \mathrm{x}$ ). (A) Heterocapsa rotundata, (B) Heterosigma akashiwo, (C) Prorocentrum minimum, (D) Heterocapsa triquetra, (E) Cochlodinium polykrikoides, and (F) Chattonella ovata. Each IR value was calculated by exploration from a linear regression curve on the number of prey cells inside an algal predator cell over incubation time (see 'Materials and methods' for calculation). Symbols represent treatment means ( $\pm 1 \mathrm{SE}$ ). Curves were by fitted by a Michaelis-Menten equation (Eq. 3) using all treatments in the experiment. Note different scales on axes

$\mathrm{ml}^{-1}$, but increased slowly or became saturated at higher prey concentrations. The bacterial concentrations in Korean waters in the present study ranged from $7.6 \times 10^{5}$ to $1.3 \times 10^{7}$ cells $\mathrm{ml}^{-1}$, but most bacterial concentrations ranged from 5 to $10 \times 10^{6}$ cells $\mathrm{ml}^{-1}$. Therefore, even a small change in bacterial concentrations may give rise to a marked effect on the ingestion rates of red-tide algae on natural populations of marine bacteria in Korean waters. There is a possibility that the addition of FLB into natural populations of marine bacteria would result in overestimation of the ingestion rates of red-tide algae on marine bacteria. When the ingestion rates of the dominant red-tide algae on the natural populations of marine bacteria are calculated by using the equations in Fig. 5 along with the abundances of bacteria and added FLB in Table 3, the rates obtained without FLB were theoretically lower than those with FLB by $34 \%$ [(5.0 - 3.3)/5.0 $\times$ 100] for Heterocapsa rotundata, 13 to $22 \%$ for $H$. triquetra, 3 to $11 \%$ for Heterosigma akashiwo 7 to $26 \%$ for Prorocentrum minimum $/ P$. triestinum, and 15 to $38 \%$ for Cochlodinium polykrikoides. It is occasionally difficult to determine the abundances of natural populations of bacteria just prior to adding FLB, and, thus, the ratios of the actual initial abundances of FLB to the abundances of the natural population of bacteria could be wide. Therefore, when the FLB method is used to measure the ingestion rates of red-tide algae on the natural population of bacteria, the possibility of overestimation should be considered based on the data on ingestion rates as a function of bacterial concentration.

Data from these studies show that the maximum ingestion rates of 6 red-tide algae on bacteria are not significantly affected by the ESDs of these algae ( $p>$ 0.1 , linear regression ANOVA), although the largest red-tide alga, Chattonella ovata, has the maximum ingestion rate (Fig. 6). In field experiments, the mean ingestion rates of the dominant red-tide algae Heterosigma akashiwo, Prorocentrum minimum and/or P. triestinum, and Cochlodinium polykrikoides were not significantly different, although their sizes were different. Therefore, the size of the red-tide algae may not be an important factor affecting the ingestion rates of bacteria by the red-tide algae tested in the present study.

The smallest red-tide alga, Heterocapsa rotundata, was able to acquire $76 \%$ of its body carbon from bacteria in a day. Assuming that the growth efficiency of $H$. rotundata feeding exclusively on bacteria is 30 to $40 \%$, this alga is capable of dividing once per 3 to 4 d. Bacteria may support the positive growth of small redtide algae and the formation of red-tide patches. However, it is possible that bacteria do not support the growth of the large red-tide algae $H$. triquetra, Cochlodinium polykrikoides, or Chattonella ovata, because they can obtain only $<4 \%$ of their body carbon from bacteria in a day. The maximum ingestion rates of marine 
Table 5. Ingestion rates and carbon acquisition of algal predators on marine bacteria as a function of bacterial concentration. Parameters are for the functional response from Eq. (3) as presented in Fig. 5. CPA: carbon content per algal cell (pg C cell ${ }^{-1}$ ); $\mathrm{CPB}$ : carbon content per bacterial cell used in each experiment $\left(\mathrm{pg} \mathrm{C} \mathrm{cell}^{-1}\right) ; I_{\max }$ : maximum ingestion rate $\left(\right.$ cells alga ${ }^{-1} \mathrm{~h}^{-1}$; parentheses: pg C alga $\left.{ }^{-1} \mathrm{~h}^{-1}\right) ; C_{\text {max }}$ : maximum clearance rate $\left(\mathrm{nl} \mathrm{alga}^{-1} \mathrm{~h}^{-1}\right) ; \mathrm{AC}$ : carbon acquired from bacteria by an algal predator per day (pg C predator ${ }^{-1} \mathrm{~d}^{-1}$ ); \% Body carbon: acquired carbon as percentage of predator's body carbon; DIN: dinoflagellate; RAP: raphidophyte. CPA was estimated from cell volume according to Strathmann (Strathmann 1967), and CPB, according to Simon \& Azam (1989), recalculated by Norland (1993)

\begin{tabular}{|llcccrrr|}
\hline & Species & CPA & CPB & $I_{\max }$ & $C_{\max }$ & AC & \% Body carbon \\
\hline Fig. 5A & Heterocapsa rotundata (DIN) & 20 & 0.052 & $12.2(0.63)$ & 1.4 & 15.2 & 76.1 \\
Fig. 5B & Heterosigma akashiwo (RAP) & 110 & 0.049 & $11.7(0.57)$ & 2.6 & 13.8 & 12.5 \\
Fig. 5C & Prorocentrum minimum (DIN) & 130 & 0.067 & $21.9(1.47)$ & 2.3 & 35.2 & 27.1 \\
Fig. 5D & Heterocapsa triquetra (DIN) & 220 & 0.055 & $6.0(0.33)$ & 1.3 & 7.9 & 3.6 \\
Fig. 5E & Cochlodinium polykrikoides (DIN) & 930 & 0.035 & $17.4(0.61)$ & 1.0 & 14.6 & 1.6 \\
Fig. 5F & Chattonella ovata (RAP) & 2870 & 0.070 & $24.5(1.72)$ & 4.5 & 41.2 & 1.4 \\
\hline
\end{tabular}

bacteria by $H$. triquetra and C. polykrikoides $(0.3$ and 0.6 pg C alga ${ }^{-1} \mathrm{~h}^{-1}$, respectively) are only ca. 20 and $10 \%$ of those of the same algal predators on an unidentified cryptophyte $\left(\mathrm{ESD}=5.6 \mu \mathrm{m} ; 1.6\right.$ and $6.7 \mathrm{pg} \mathrm{C}$ alga $^{-1} \mathrm{~h}^{-1}$, respectively; Jeong et al. 2004, 2005b). H. triquetra and C. polykrikoides are likely to obtain more carbon from the cryptophyte than from bacteria in the event that both prey items are abundant. Low maximum volume-specific clearance rates of $H$. triquetra and $C$. polykrikoides on marine bacteria (110 to $730 \mathrm{~h}^{-1}$ ) also suggest that bacteria are not suitable prey for the growth of these algae, but they may be considered as supplementary prey.

The maximum ingestion rates of the red-tide algae on marine bacteria under the laboratory conditions provided in the present study ( 6 to 25 cells alga ${ }^{-1} \mathrm{~h}^{-1}$ ) are comparable to those of the HNFs Jakoba libera and Pteriodomonas danica (4 to 10 cells $\mathrm{HNF}^{-1} \mathrm{~h}^{-1}$; EcclestonParry \& Leadbeater 1994, Zubkov \& Sleigh 1995). However, they are considerably lower than those shown by the ciliate Uronema sp. (150 to 380 cells ciliate ${ }^{-1} \mathrm{~h}^{-1}$; Alonso et al. 2000). The maximum clearance ingestion rates of the red-tide algae on marine bacteria under the laboratory conditions provided in the present study (1.0 to $4.5 \mathrm{nl} \mathrm{alga}^{-1} \mathrm{~h}^{-1}$ ) are comparable to those of the HNFs Codosiga gracilis, J. libera, P. danica, and Para-

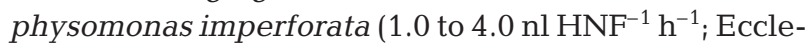
ston-Parry \& Leadbeater 1994, Zubkov \& Sleigh 1995). However, they are considerably lower than those shown by the ciliate Uronema sp. (50 to $560 \mathrm{nl}$ ciliate ${ }^{-1} \mathrm{~h}^{-1}$; Alonso et al. 2000). Therefore, the red-tide algae tested in the present study may sometimes compete with several HNF species for bacterial prey, if they co-occur.

We measured the ingestion rates of the red-tide algae on bacteria at a light intensity of $30 \mu \mathrm{E} \mathrm{m}^{-2} \mathrm{~s}^{-1}$. The ingestion rates of the mixotrophic dinoflagellates Fragilidium subglobosum and Karlodinium micrum increased continuously or increased and then were saturated with increasing light intensity up to ca. $100 \mu \mathrm{E} \mathrm{m}^{-2} \mathrm{~s}^{-1}$ (Hansen \& Nielsen 1997, Li et al. 2000, Skovgaard et al. 2000), while those of $F$. cf. mexicanum (20 to $200 \mu \mathrm{E} \mathrm{m} \mathrm{m}^{-2} \mathrm{~s}^{-1}$; Jeong et al. 1999) and Prorocentrum minimum (between 6 and $100 \%$ incident light intensity; Stoecker et al. 1997) were not significantly affected by light intensity under the provided conditions. Therefore, the effect of light intensity on feeding in red-tide algae may depend on the species; thus, further studies using diverse red-tide algal species are necessary.

\section{Ecological importance}

The results of the present study are ecologically important for planktonic communities in the following ways. (1) All 17 red-tide algal species tested in the field and laboratory in the present study ingested bacteria. Most red-tide algae may be able to feed on marine bacteria. (2) During some red tides, the dominant red-

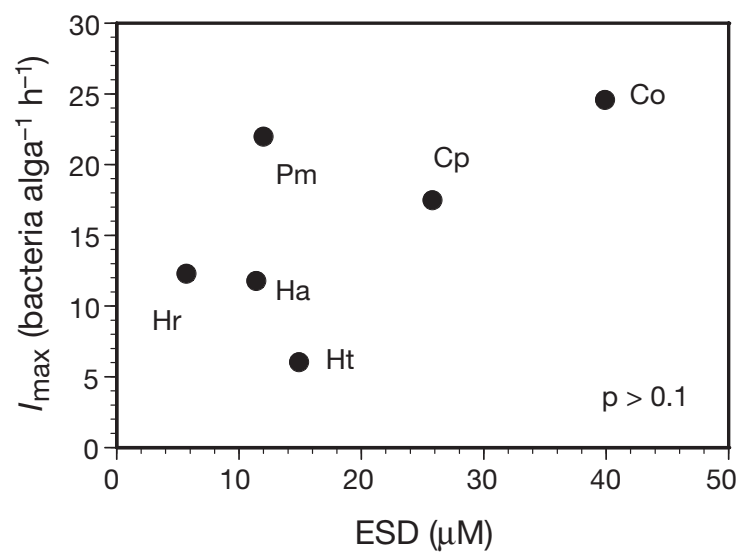

Fig. 6. Maximum ingestion rates $\left(I_{\max }\right)$ of 6 red-tide algae on bacteria, as a function of algal predator size (equivalent spherical diameters, ESD). Co: Chattonella ovata; Cp: Cochlodinium polykrikoides; Ha: Heterosigma akashiwo; Hr: Heterocapsa rotundata; Ht: Heterocapsa triquetra; Pm: Prorocentrum minimum 
tide algae are the most effective predators of marine bacteria among protistan predators (algae, HNFs, and ciliates). As described above, the importance of redtide algae as predators of bacteria, relative to HNFs and ciliates, depends on the algal species and abundances. The possible high grazing impact of red-tide algae may be partially responsible for lower bacterial grazing rates than those expected by calculations based on the assumption that HNFs are the main consumers of bacteria (e.g. Vaque et al. 2002). (3) Some red-tide algae are prey for ciliates (Jeong et al. 1999), but they can sometimes compete with the ciliates for bacterial prey. (4) Bacteria may be too small to be ingested by the filter-feeding copepods, while many red-tide algae are eaten by copepods (Nival \& Nival 1976, Berggreen et al. 1988, Jeong 1995). Therefore, red-tide algae might be a link between bacteria and some zooplankters that are unable to directly ingest bacteria. (5) Usually, the populations of bacteria increase when phytoplankton biomass increases, because the dissolved organic matter from phytoplankton may enhance the growth of bacteria (e.g. Kamiyama et al. 2000). However, uncoupling between abundances of bacteria and phytoplankton has sometimes been observed (e.g. Bird \& Karl 1999). Grazing by red-tide algae on bacteria may be partially responsible for this uncoupling. If an alga that is capable of feeding on bacteria is the causative species for a bloom (i.e. mixotrophic dinoflagellates, nanoflagellates, and microflagellates) and if grazing impact by the alga on bacteria is considerable, the abundance of bacteria may be rapidly reduced during algal blooms. The population dynamics of marine bacteria and phytoplankton in red tides may depend on whether the causative species are mixotrophic dinoflagellates (able to feed on bacteria) or exclusively autotrophic diatoms (unable to feed on bacteria).

Acknowledgements. We thank Jae Yeon Park, Myeong Ok Park, Tae Hoon Kim, Seong Taek Kim, Jae Yoon Song, Jong Hyeok Kim, and Nam Seon Kang for technical support. This paper was funded by a grant from the Korean Research Foundation (R02-2004-000-10033-0) and an NRL grant from MOST \& KOSEF (M1-0302-00-0068).

\section{LITERATURE CITED}

Albright LJ, Sherr EB, Sherr BF, Fallon RD (1987) Grazing of ciliated protozoa on free and particle-attached bacteria. Mar Ecol Prog Ser 38:125-129

Alonso MC, Rodriguez V, Rodriguez J, Borrego JJ (2000) Role of ciliates, flagellates and bacteriophages on the mortality of marine bacteria and on dissolved-DNA concentration in laboratory experimental systems. J Exp Mar Biol Ecol 244:239-252

Azam F, Fenchel T, Field JG, Gray JS, Meyer-Reil LA, Thingstad F (1983) The ecological role of water-column microbes in the sea. Mar Ecol Prog Ser 10:257-263
Berggreen B, Hansen B, Kiørboe T (1988) Food size spectra, ingestion and growth of the copepod Acartia tonsa during development: implications for determination of copepod production. Mar Biol 99:341-352

Bird DF, Karl DM (1999) Uncoupling of bacteria and phytoplankton during the austral spring bloom in Gerlache Strait, Antarctic Peninsula. Aquat Microb Ecol 19:13-27

Bloem J, Bar-Gilissen MJB (1989) Bacterial activity and protozoan grazing potential in a stratified lake. Limnol Oceanogr 34:297-309

Bockstahler KR, Coats DW (1993) Grazing of the mixotrophic dinoflagellate Gymnodinium sanguineum on ciliate populations of Chesapeake Bay. Mar Biol 116: 477-487

Boenigk J, Novarino G (2004) Effect of suspended clay on the feeding and growth of bacterivorous flagellates and ciliates. Aquat Microb Ecol 34:181-192

Chang J, Carpenter EJ (1994) Inclusion bodies in several species of Ceratium Schrank (Dinophyceae) from the Caribean Sea examined with DNA-specific staining. J Plankton Res 16:197-202

Cho BC, Azam F (1990) Biogeochemical significance of bacterial biomass in the ocean's eutrophic zone. Mar Ecol Prog Ser 63:253-259

Cole JJ, Findlay S, Pace ML (1988) Bacterial production in fresh and saltwater ecosystems: a cross-system overview. Mar Ecol Prog Ser 43:1-10

Doucette GJ, McGovern ER, Babinchak JA (1999) Algicidal bacteria active against Gymnodinium breve (Dinophyceae). I. Bacterial isolation and characterization of killing activity. J Phycol 35:1447-1454

Eccleston-Parry JD, Leadbeater BSC (1994) A comparison of the growth kinetics of six marine heterotrophic nanoflagellates fed with one bacterial species. Mar Ecol Prog Ser 105:167-177

Epstein SS (1997) Microbial food webs in marine sediments. I. Trophic interactions and grazing rates in two tidal flat communities. Microb Ecol 34:188-198

Fenchel T (1982) Ecology of heterotrophic microflagellates. IV. Quantitative occurrence and importance as bacterial consumers. Mar Ecol Prog Ser 9:35-42

Granéli E, Anderson DM, Carlsson P, Maestrini SY (1997) Light and dark carbon uptake by Dinophysis species in comparison to other photosynthetic and heterotrophic dinoflagellates. Aquat Microb Ecol 13:177-186

Guillard RRL, Ryther JH (1962) Studies of marine planktonic diatoms. I. Cyclotella nana Hustedt and Detonula confervacea (Cleve) Grun. Can J Microbiol 8:229-239

Hansen PJ, Nielsen TG (1997) Mixotrophic feeding of Fragilidium subglobosum (Dinophyceae) on three species of Ceratium: effects of prey concentration, prey species and light intensity. Mar Ecol Prog Ser 147:187-196

Imai I, Sunahara T, Nishikawa T, Hori Y, Kondo R, Hiroishi S (2001) Fluctuations of the red tide flagellates Chattonella spp. (Raphidophyceae) and the algicidal bacterium Cytophaga sp. in the Seto Inland Sea, Japan. Mar Biol 138: 1043-1049

Jacobson DM, Anderson DM (1996) Widespread phagocytosis of ciliates and other protists by marine mixotrophic and heterotrophic thecate dinoflagellates. J Phycol 32:279-285

Jeong HJ (1995) The interactions between microzooplanktonic grazers and dinoflagellates causing red tides in the open coastal waters off southern California. PhD thesis, University of California, San Diego

Jeong HJ, Shim JH, Kim JS, Park JY, Lee CW, Lee Y (1999) The feeding by the thecate mixotrophic dinoflagellate Fragilidium cf. mexicanum on red tide and toxic dinoflagellates. Mar Ecol Prog Ser 176:263-277 
Jeong HJ, Yoo YD, Kim JS, Kim TH, Kim JH, Kang NS, Yih WH (2004) Mixotrophy in the phototrophic harmful alga Cochlodinium polykrikoides (Dinophycean): prey species, the effects of prey concentration and grazing impact. J Eukaryot Microbiol 51:563-569

Jeong HJ, Park JY, Rho JH, Park MO and 5 others (2005a) Feeding by the red-tide dinoflagellates on the cyanobacterium Synechococcus. Aquat Microb Ecol 41:131-143

Jeong HJ, Yoo YD, Park JY, Song JY, Kim ST, Lee SH, Kim KY, Yih WH (2005b) Feeding by the phototrophic red-tide algal predators: five species newly revealed and six species previously known to be mixotrophic. Aquat Microb Ecol 40:133-150

Jeong HJ, Yoo YD, Seong KA, Kim JH and 5 others (2005c) Feeding by the mixotrophic algal predator Gonyaulax polygramma: mechanisms, prey species, the effects of prey concentration, and grazing impact. Aquat Microb Ecol 38:249-257

Kamiyama T, Itakura S, Nagasaki K (2000) Changes in microbial loop components: effects of a harmful algal bloom formation and its decay. Aquat Microb Ecol 21:21-30

Kim M, Yoshinaga I, Imai I, Nagasaki K, Itakura S, Ishida Y (1998) A close relationship between algicidal bacteria and termination of Heterosigma akashiwo (Raphidophyceae) blooms in Hiroshima Bay, Japan. Mar Ecol Prog Ser 170: 25-32

Lee SH (1993) Measurement of carbon and nitrogen biomass and biovolume from naturally derived marine bacterioplankton. In: Kemp PF, Sherr BF, Sherr EB, Cole JJ (eds) Aquatic microbial ecology. Lewis Publishers, Boca Raton, FL, p 319-325

Lee S, Fuhrman JA (1987) Relationship between biovolume and biomass of natural derived marine bacterioplankton. Appl Environ Microb 53:1298-1303

Legrand C, Granéli E, Carlsson P (1998) Induced phagotrophy in the photosynthetic dinoflagellate Heterocapsa triquetra. Aquat Microb Ecol 15:65-75

Li A, Stoecker DK, Coats DW (2000) Mixotrophy in Gyrodinium galathaenum (Dinophyceae): grazing responses to light intensity and inorganic nutrients. J Phycol 36:33-45

Mayali X, Azam F (2003) Do algicidal bacteria significantly influence the dynamics and the demise of marine algae blooms? J Phycol 39 S1:40

McManus GB, Fuhrman JA (1988) Clearance of bacteria sized particles by natural populations of nanoplankton in the Chesapeake Bay outflow plume. Mar Ecol Prog Ser 42: 199-206

Nival P, Nival S (1976) Particle retention efficiencies of a herbivorous copepod, Acartia clausi (adult and copepodite stages): effects on grazing. Limnol Oceanogr 21:25-49

Norland S (1993) The relationship between biomass and volume of bacteria. In: Kemp PF, Sherr BF, Sherr EB, Cole JJ (eds) Aquatic microbial ecology. Lewis Publishers, Boca Raton, FL, p 303-307

Nygaard K, Tobiesen A (1993) Bacterivory in algae: a survival strategy during nutrient limitation. Limnol Oceanogr 38: 273-279

Editorial responsibility: Evelyn and Barry Sherr (Contributing Editors), Corvallis, Oregon, USA
Patterson DJ, Larsen J (1991) General introduction. In: Patterson DH, Larsen J (eds) The biology of free-living heterotrophic flagellates. Spec Vol 45, The Systematics Association, Clarendon Press, Oxford, p 1-5

Porter KG, Feig YS (1980) The use of DAPI for identifying and counting aquatic microflora. Limnol Oceanogr 25:943-948

Posch T, Simek K, Vrba J, Pernthaler J, Nedoma J, Sattler B, Sonntag B, Psenner R (1999) Predator-induced changes of bacterial size-structure and productivity studied on an experimental microbial community. Aquat Microb Ecol 18: 235-246

Sherr BF, Sherr EB, Fallon RD (1987) Use of monodispersed, fluorescently labeled bacteria to estimate in situ protozoan bacterivory. Appl Environ Microbiol 53:958-965

Sherr EB, Sherr BF, Verity PG (2002) Distribution and relation of total bacteria, active bacteria, bacterivory, and volume of organic detritus in Atlantic continental shelf waters off Cape Hatteras, NC, USA. Deep-Sea Res B 49:4571-4585

Sieburth JM (1984) Protozoan bacterivory in pelagic marine waters. In: Hobbie JE, Williams PJI (eds) Heterotrophic activity in the sea. Plenum Publishing, New York, p 405-444

Simon M, Azam F (1989) Protein content and protein synthesis rates of planktonic marine bacteria. Mar Ecol Prog Ser 51:201-213

Skerratt JH, Bowman JP, Hallegraeff G, James S, Nichols PD (2002) Algicidal bacteria associated with blooms of a toxic dinoflagellate in a temperate Australian estuary. Mar Ecol Prog Ser 244:1-15

Skovgaard A, Hansen PJ, Stoecker DK (2000) Physiology of the mixotrophic algal predator Fragilidium subglobosum. I. Effects of phagotrophy and irradiance on photosynthesis and carbon content. Mar Ecol Prog Ser 201:129-136

Smalley GW, Coats DW, Stoecker DK (2003) Feeding in the mixotrophic algal predator Ceratium furca is influenced by intracellular nutrient concentrations. Mar Ecol Prog Ser 262:137-151

Stoecker DK (1999) Mixotrophy among dinoflagellates. J Eukaryot Microbiol 24:397-401

Stoecker DK, Li A, Coats DW, Gustafson DE, Nannen MK (1997) Mixotrophy in the algal predator Prorocentrum minimum. Mar Ecol Prog Ser 152:1-12

Strathmann RR (1967) Estimating the organic carbon content of phytoplankton from cell volume or plasma volume. Limnol Oceanogr 12:411-418

Vaque D, Calderon-Paz JI, Guixa-Boixereu N, Pedros-Alio C (2002) Spatial distribution of microbial biomass and activity (bacterivory and bacterial production) in the northern Weddell Sea during the austral summer (January 1994). Aquat Microb Ecol 29:107-121

Vargas CA, Gonzalez HE (2004) Plankton community structure and carbon cycling in a coastal upwelling system. II. Microheterotrophic pathway. Aquat Microb Ecol 34:165-180

Zubkov MV, Sleigh MA (1995) Bacterivory by starved marine heterotrophic nanoflagellates of two species which feed differently, estimated by uptake of dual radioactivelabelled bacteria. FEMS Microb Ecol 17:57-66

Submitted: September 28, 2005; Accepted: February 26, 2006 Proofs received from author(s): August 29, 2006 